\title{
Used Foundry Sand in Cement Mortars and Concrete Production
}

\author{
Saveria Monosi, Daniela Sani* and Francesca Tittarelli
}

Università Politecnica delle Marche, Dipartimento di Fisica, Ingegneria dei Materiali e del Territorio (FIMET), Italy

\begin{abstract}
Used foundry sands represent the highest amount of solid wastes generated by foundries. Classified by European Union regulations as non hazardous waste, they represent a relevant source to be reused in several industrial sectors, in building construction primarily.

In present paper, the properties of mortars and concretes containing different dosages of used foundry sand (UFS) as partial replacement of sand were investigated in both fresh and hardened conditions. In particular, higher percentages of addition, but lower if referred to the whole aggregate (fine and coarse), were considered in concretes than in mortars. Both mortars and concretes were evaluated with respect to consistency of the fresh mixture and compressive strength of the hardened material. Elastic modulus determination of the hardened material was carried out on concretes.
\end{abstract}

A low $(10 \%)$ amount of used foundry sand does not change the mortar's performances. In the presence of higher additions a workability decreasing can be outlined, and then a higher dosage of superplasticizer is required in order to keep it constant. Mechanical performances lower of about 20-30\% than those of the conglomerate without used foundry sand are observed. The higher penalization it seems to concern to the conglomerates of better quality (i.e. lower water-cement ratio).

Keywords: Used foundry sand, spent foundry sand, concrete compressive strength, mortar compressive strength, concrete aggregate replacing, mortar aggregate replacing.

\section{INTRODUCTION}

Used Foundry sand (UFS) is a discarded material coming from ferrous and nonferrous metal-casting industry. It's a mixture of high quality size-specific silica sand, few amount of impurity of ferrous and nonferrous by-products from the metal casting process itself and a variety of binders.

The silica sand is used as moulding material, for ferrous (iron and steel) and nonferrous (copper, aluminium, brass) metal castings, mainly because of its thermal conductivity. The raw sand is normally of a higher quality than the typical bank run or natural sands used in fill construction sites. In the casting process, moulding sands are recycled and reused multiple times, small residues of ferrous and non-ferrous byproducts often come from the recycling process. Before to be reused, silica sand needs to be cleaned by means of screening systems and magnetic separators to segregate reusable sand from other wastes and to separate particles of varying sizes $[1,2]$.

As moulding material, the sand is compacted and shaped according to the mould pattern that is going to be produced, as well as to create cavities that are not practical to produce by normal moulding operations, the cores. Because of that, UFSs contain a variety of binders (a binder is required to give binding action to the incoherent sandy mixtures) depending on the specific application for which they were used.

*Address correspondence to this author at the Università Politecnica delle Marche, Dipartimento di Fisica, Ingegneria dei Materiali e del Territorio (FIMET), Italy; Tel: +39 071 2204726; Fax: +39 071 2204627;

E-mail: d.sani@univpm.it
Although UFS is partially a recycled material itself, as successfully recycled and reused through many production cycles, after many times it loses its characteristics especially the cleanliness and the uniformity ones. Becoming unsuitable in the manufacturing process, it's discarded as waste.

Typically, the automotive industry and its parts suppliers are the major generators of foundry sand (about $95 \%$ of the estimated UFS). They employ about 1 ton of foundry sand for each ton of iron or steel casting produced, with a non negligible impact especially from a sustainable development point of view. According to the American Foundry Society (AFS), a metal casting industry group, the metal-casting process generates 9.4 million tons of foundry sand annually (2007 data) [3].

At present, although a great attention to environmental issues, the general trend is still to dispose UFSs in landfills, sometimes utilised as landfill daily cover. The American Foundry Society estimates that 6.8 million tons of foundry sand (2007 data) [3] was disposed in landfills, approximately the $2 / 3$ of the total production. Several evident drawbacks could be listed due to this trend:

- early closure of the material life cycle with consequently more consumption of virgin raw materials;

- $\quad$ saturation of existing landfills and soil pollution in unmanaged landfill cases;

- $\quad$ release of leachable contaminants, absorbed by the sand during the moulding process and casting operations, like heavy metals (cadmium, lead, copper, nickel, and zinc) and phenols; 
- $\quad$ economic impact, referring in particular to logistic costs in UFS transportation (sometimes landfill is not so close to the foundry);

- environmental impact, linked to the climate change, due to $\mathrm{CO}_{2}$ emission because of the previous drawbacks.

Furthermore, according to EC regulations $[4,5]$, UFS is classified as non-hazardous waste and, consequently, it has an important intrinsic economic value, especially in terms of iron and steel. Recently, a numbers of applied researches [69], including the patent [10], addressed to investigate the feasibility to re-employ UFSs in other industrial sectors than ferrous. The most suitable one seems the construction industry, because of UFS employ in several construction materials, like: Portland cement clinker, structural concrete, brickworks, building conglomerates, road base, structural fill, flow-able fill, soil amendment, or as the fine aggregate portion of concrete or hot-mix asphalt [11-13]. In addition, some sand can be used as a high-end additive to industrial materials, such as plastics, to provide specific textures and colours [12].

Detailed quantitative data on the various beneficial applications of foundry sand have not been well documented in the past. Recently, a preliminary survey has been conducted by AFS [14] pointing out that a small amount of UFS is still used in Portland cement clinker. This seems due to the transportation costs to joint the final destination plant, especially considering the high amounts daily production of the foundry. However, according to the Portland Cement Association foundry sand is being used by a number of North American cement kilns [15-17].

As far as Europe it concerns, data are pointing out an increasing interest on UFS technical properties in conglomerates production and performances [18, 19]. Moreover, the environmental aspects and compatibility have been investigated in order to point out the prerequisites for the USF utilisation [20, 21].

The present work aims to contribute at studies on the UFS usability as construction material. In particular, it focus on structural concretes and mortars, by investigating the feasibility to partially replace natural sand with UFSs, and by characterising the new conglomerate mixtures in both fresh and hardened conditions.

\section{BASIC LITERATURE REVIEW ON USED FOUNDRY SAND PROPERTIES}

Due to the foundry sand high concentration and annually production of metal industries - especially in USA - applied research on UFS start since 1980. In particular, UFS has extensively investigated as a constituent material for controlled low-strength materials $[1,2,9,22,23]$.

The classification (physical and chemical) and the behaviour of foundry sand strictly depend on the type of casting process and the industry sector from which it originates, and especially from the type of binder systems used in the process. Typically, two types of binder systems, with different physical and environmental characteristics, are used: clay and chemical binder. Accordingly, foundry sand is categorised as: clay bonded system (green sand) and chemically bonded system. Generally, green sand is the most commonly used: it constitutes about the $90 \%$ of casting volume [24].

Green sand is composed of:

- $\quad$ high quality silica sand (85-95\%) - the bulk medium that resists high temperature;

- $\quad$ bentonite clay (4-10\%) - used as binder;

- $\quad$ carbonaceous additive (2-10\%) - added to improve the casting surface finish;

- $\quad$ water (2-5\%) - to adjust plasticity.

Green sand has a clay content that results in percentage of material that passes at $75 \mu \mathrm{m}$ (sieve n.200, ASTM C136 06 Standard Test Method for Sieve Analysis of Fine and Coarse Aggregates) and adheres together due to clay and water. Due to carbon content, it looks black in colour, or sometimes gray. It also contains trace chemicals such as $\mathrm{MgO}, \mathrm{K}_{2} \mathrm{O}$, and $\mathrm{TiO}_{2}$ [24].

Chemically bonded sand consists of silica sand and chemical binder that is activated by a catalyst. Generally, chemically bonded sands are $93-99 \%$ silica and $1-3 \%$ chemical binder. There are various types of chemical binder systems used in the foundry industry (chemical composition usually proprietary). Most consists of organic, like phenolicurethanes, epoxy-resins, furfyl alcohol, although some systems use inorganic binders (i.e. sodium silicates).

Commonly, they are used in core making where high strengths are necessary to withstand the heat of molten metal, but also in mould making. Silica sand is thoroughly mixed with the chemicals; a catalyst initiates the reaction that cures and hardens the mass. The chemically bonded sand is typically a medium tan or off-white colour.

Used foundry sand is generally sub-angular to round in shape. The grain size distribution is uniform: $85-95 \%$ of the material ranging between 0.6 and $0.15 \mathrm{~mm} ; 5-12 \%$ can be smaller than $75 \mu \mathrm{m}$. The specific gravity of the foundry sand can vary according to the category; often it ranges between 2200 and $2600 \mathrm{~kg} / \mathrm{m}^{3}$. Used foundry sand has low absorption capacity and is non-plastic [25].

\section{MATERIALS AND METHODOLOGY}

The present work concerns the investigation of UFS utilisation effect on both mortars and concretes. In particular, the performances of conglomerates (mortars and concretes), at different water/cement $(\mathrm{w} / \mathrm{c})$ ratios, are investigated. The aims is to establish the amount of used foundry sand that can be added in mixture without too heavy penalizations, principally in terms of workability, mechanical performances (i.e. compressive strength and dynamic elastic modulus) and drying shrinkage.

A commercial Portland-limestone blended cement type CEM II/A-L 42.5 R in accordance with European Standards EN-197/1 is used.

Cement is characterized by Blaine fineness of $0.415 \mathrm{~m}^{2} / \mathrm{g}$ (UNI EN 196/6) and density of $3100 \mathrm{~kg} / \mathrm{m}^{3}$. The chemical composition of cement is shown in Table $\mathbf{1}$. The UFS, object of this research, is green sand (Fig. 1) coming from the metal-casting moulding process of an Italian foundry which produces metal component for the automotive industry. 
(a)

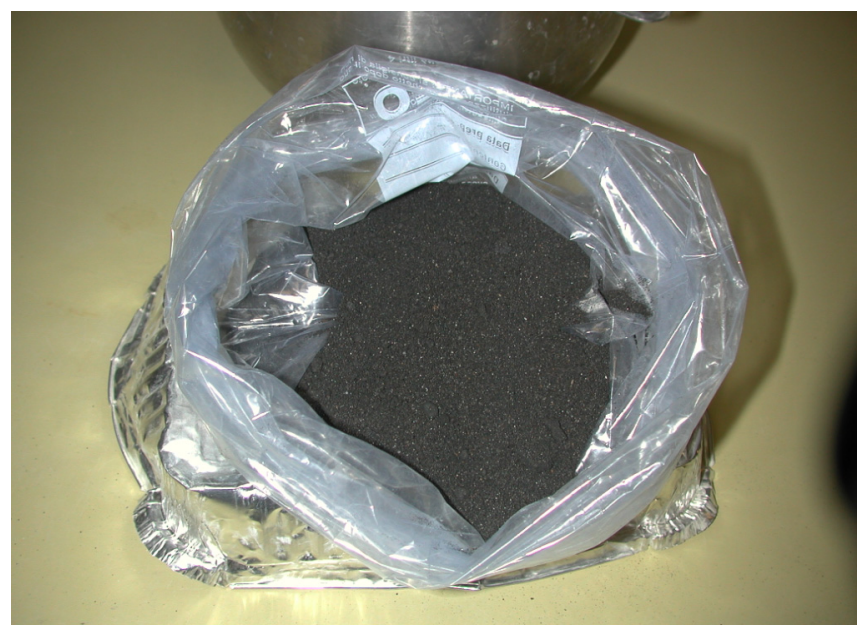

(b)

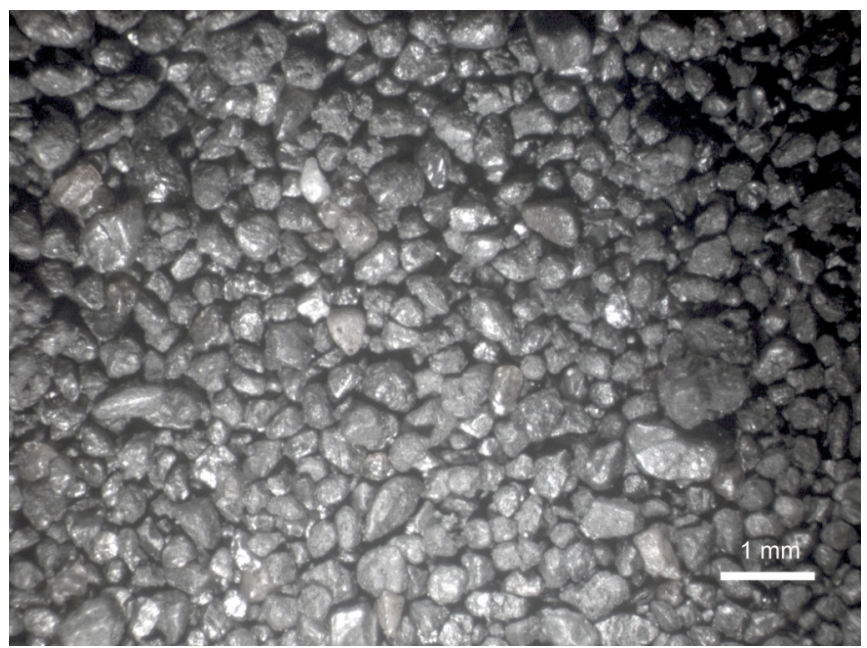

Fig. (1). Used Foundry Sand (UFS) - an Italian foundry green sand: a) normal view b) magnified in optical microscopy.

According to the European Union and National regulations [26-28], the industry dispose it as non-hazardous waste. The chemical analyses (including leaching tests) confirm the non-hazardous nature of the discarded sand (Table 2). As far as the organic content it concerns, the measured dissolved organic carbon (DOC) results under the Italian low limit (i.e. $<80 \mathrm{mg}^{-1}$ ).

The UFS was physically and chemically characterized in terms of specific weight (UNI EN 1097-6:2002), X-Ray diffraction analysis (on the fraction finer than $75 \mu \mathrm{m}$ ) and Differential Thermal Analysis. Particle-size distribution was evaluated by sieve analysis (UNI EN 933-1).

About UFS physical properties, the specific weight is equal to $2260 \mathrm{~kg} / \mathrm{m}^{3}$. Sieve analysis shows a high rate of material finer than $75 \mu \mathrm{m}$, due to the large amount of binder present in the sand (Fig. 2).

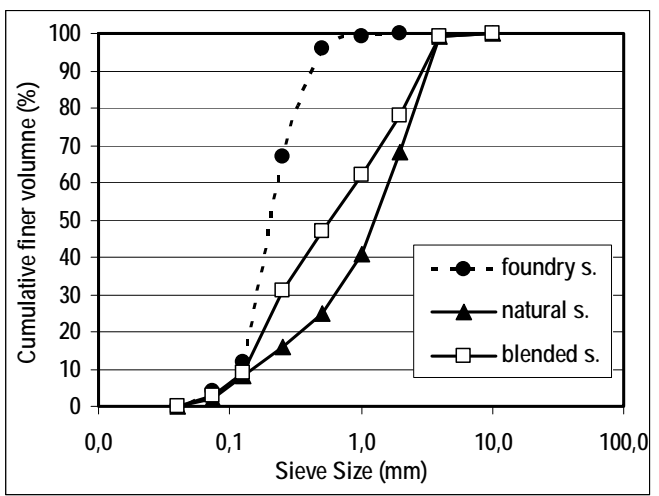

Fig. (2). Sieve analysis curves of the foundry, natural and a blended (with $30 \%$ of UFS) sand.

In Fig. (2) the UFS sieve analysis is also compared with that of the natural sand. An example of how the blend with both natural $(70 \%)$ and foundry $(30 \%)$ sand modifies the sieving curve is also shown in Fig. (2).

The binder constituents are better pointed out in Figs. (3, 4). In particular, Fig. (3) relates to the X-ray analysis, carried out on the material fraction finer than $75 \mu \mathrm{m}$, and reveals the presence of quartz and carbonates (calcite and dolomite) as well as montmorillonite. Fig. (4) relates to the Differential Thermal Analysis (DTA), carried out on UFS as received, and quantifies the amount of carbonaceous additive as about $2.8 \%$ by weight.

As far as to the mortars and concretes preparation it concerns, firstly reference mortars and concretes (control mix) are proportioned without used foundry sand (i.e. with only natural sand). For both mortar and concrete mixtures the natural aggregates consist of:

- coarse aggregate with a $22 \mathrm{~mm}$ maximum size and specific weight of $2660 \mathrm{~kg} / \mathrm{m}^{3}$;

- $\quad$ fine aggregate (natural sand) with a $4 \mathrm{~mm}$ maximum size, specific weight of $2620 \mathrm{~kg} / \mathrm{m}^{3}$.

The experimental stage plans to employ used foundry sand as a partial replacement of the fine aggregate. A set of

Table 1. Chemical Composition of the Cement

\begin{tabular}{|c|c|c|c|c|c|c|c|c|c|c|}
\hline Oxide & $\mathrm{SiO}_{2}$ & $\mathrm{Al}_{2} \mathbf{O}_{3}$ & $\mathrm{Fe}_{2} \mathbf{O}_{3}$ & $\mathbf{T i O}_{2}$ & $\mathbf{C a O}$ & $\mathbf{M g O}$ & $\mathbf{S O}_{3}$ & $\mathrm{~K}_{2} \mathbf{O}$ & $\mathrm{Na}_{2} \mathbf{O}$ & $\mathbf{L} . \mathbf{O} . \mathbf{I}$. \\
\hline \hline$\%$ & 29.67 & 3.74 & 1.80 & 0.09 & 59.25 & 1.15 & 3.25 & 0.79 & 0.26 & 11.62 \\
\hline
\end{tabular}

L.O.I. $=$ loss on ignition.

Table 2. UFS Leaching Cation Content and Dissolved Organic Carbon (DOC)

\begin{tabular}{|c|c|c|c|c|c|c|c|}
\hline Ion & Na & K & Mg & Ca & Al & Zn & DOC \\
\hline \hline $\mathrm{mg} \mathrm{l}^{-1}$ & 340 & 10.8 & 2.5 & 9.1 & 36.0 & 0.16 & $<80$ \\
\hline
\end{tabular}


mortar specimens is manufactured by replacing the $10 \%$, $20 \%, 30 \%$ by weight of natural sand with UFS. On the other hand, concrete specimens were manufactured by replacing the $7-10 \%$ of the whole aggregate weight, which corresponds to replace of about the $20-30 \%$ of the only sand weight, with UFS.

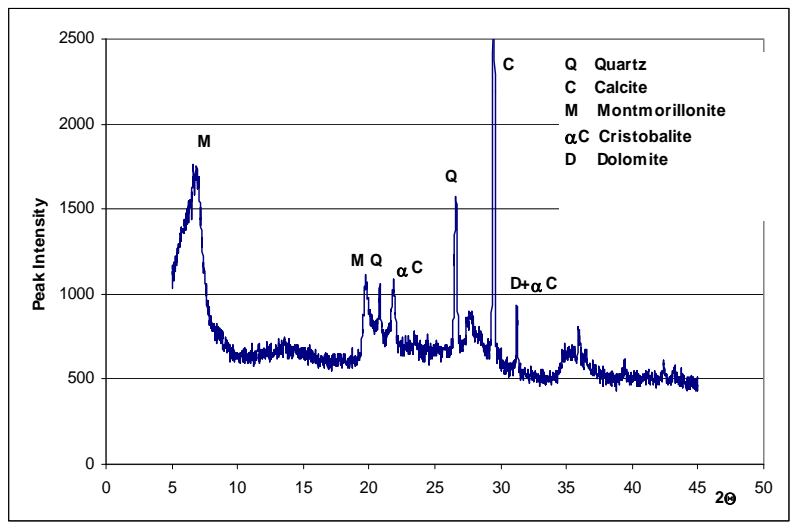

Fig. (3). X-Ray diffraction pattern of UFS finer than $75 \mu \mathrm{m}$.

Mortars (M1, M2 and M3) are manufactured with a water-cement $(\mathrm{w} / \mathrm{c})$ ratio of $0.45,0.50,0.55$; concretes $(\mathrm{C} 1$, $\mathrm{C} 2$ ) are proportioned with a water-cement ratio of 0.46 and 0.50. Compositions, including workability, are shown in Tables 3 and 4.

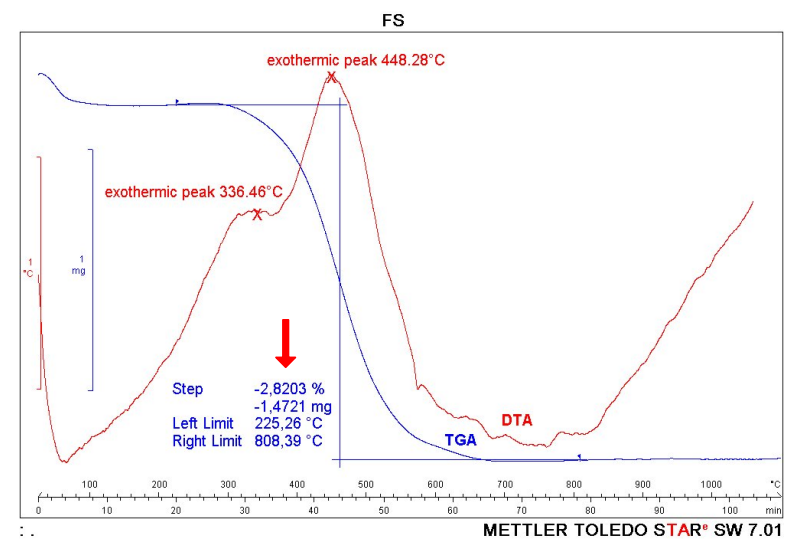

Fig. (4). Differential Thermal Analysis of UFS as it is.

At occasion UFS is pre-treated mainly to reduce the amount of binder finer fraction and to improve adhesion. In this research UFS has been cleaned by washing in water and sieving at $75 \mu \mathrm{m}$. A mortar specimen with $20 \%$ by weight of cleaned UFS has been set up in order to compare results and test the benefits to clean the UFS (see Table 3, M2-20 c).

Mixtures are proportioned maintaining, as close as possible, the same workability with and without foundry sand. To this aim, when needed, an acrylic based super plasticizer is added in the mixture to adjust workability.

The consistency test gives a slump flow - measured by vibrating table (UNI EN 1015-3) - of 110 - 145mm for mortars, and a slump value - measured by Abrams cone (UNI EN 12350-2) - of approximately 120-160mm for concretes.

Prismatic mortar specimens $(4 \times 4 \times 16 \mathrm{~cm})$ and cubic concrete specimens $(15 \times 15 \times 15 \mathrm{~cm})$ are prepared with each mixture in order to test compressive strength (UNI EN 101511 and UNI EN 12504-4) and dynamic elastic modulus (UNI EN 1015-11 and UNI EN 12504-4) and then to deduce the mechanical performance of the specimens. Compressive strength of both mortar and concrete mixtures, made with and without UFS, is determined at 1, 3, 7, 14 and 28 days of curing in order to point out the mechanical performances trend, depending on the hydration kinetic, versus time.

Moreover, concrete beams $(10 \times 10 \times 50 \mathrm{~cm})$ are appositely performed to test drying shrinkage (UNI 11307), in order to report the effects of UFS replacing on the concrete drying shrinkage.

During the first day of curing time, all mixtures are conserved into formworks. After de-moulding, they are cured in a saturated environment to prevent water evaporation. For drying shrinkage measurements, concrete beams are conserved, during all curing time, in a controlled environment, at relative humidity of about $60 \%$. The temperature is kept constant at about $20^{\circ} \mathrm{C}$.

\section{RESULTS AND DISCUSSION}

The fresh mixture data of both mortars and concretes (Tables 3 and 4) show that UFS reduces the workability when added as natural sand replacement (at same $\mathrm{w} / \mathrm{c}$ ); higher amount of superplasticizer is required in order to maintain the same workability.

The control mortar sample with w/c equal to 0.50 requires an addition of $0.5 \%$ by cement weight, while mortars containing UFS need an addition up to $1.8 \%$. Similarly, concrete mixture containing UFS needs a

Table 3. Mortar Composition and Fresh Mixture Workability

\begin{tabular}{|c|c|c|c|c|c|c|c|c|c|}
\hline cement $(\mathrm{kg})$ & 500 & 500 & 500 & 500 & 480 & 480 & 480 & 480 & 510 \\
\hline foundry sand $(\mathrm{kg})$ & - & 150 & 300 & 450 & - & 290 & 290 & 435 & 455 \\
\hline water $(\mathrm{kg})$ & 250 & 250 & 250 & 250 & 265 & 265 & 265 & 265 & 230 \\
\hline superplasticizer (\%) & 0.5 & 0.5 & 1.5 & 1.8 & - & 0.9 & - & 1.2 & 2 \\
\hline slump flow (mm) & 142 & 130 & 115 & 110 & 145 & 123 & 130 & 118 & 116 \\
\hline
\end{tabular}


superplasticizer dosage. The dosage ranges from $1.4 \%$ to $1.7 \%$ by cement weight, depending on the $\mathrm{w} / \mathrm{c}$ ratio utilised. This increase in superplasticizer addition should be considered quite high when compared to that introduced in ordinary conglomerate.

Fresh mixture unit weight (UNI EN 12350-6) and entrapped air content (UNI EN 12350-7) do not point out any relevant differences with and without foundry sand (i.e. shown on Table 4).

Table 4. Concrete Composition and Fresh Mixture Performance

\begin{tabular}{|l|c|c|c|c|c|}
\hline \multicolumn{1}{|c|}{ MIX } & C1 & C1-7 & C1-10 & C2 & C2-10 \\
\hline \hline cement (kg) & 350 & 350 & 350 & 355 & 355 \\
\hline natural sand (kg) & 645 & 515 & 460 & 655 & 456 \\
\hline coarse aggregate (kg) & 1210 & 1210 & 1210 & 1230 & 1230 \\
\hline foundry sand (kg) & - & 130 & 185 & - & 187 \\
\hline water $(\mathrm{kg})$ & 175 & 175 & 175 & 165 & 165 \\
\hline water/cement (w/c) (-) & 0.50 & 0.50 & 0.50 & 0.46 & 0.46 \\
\hline superplasticizer \% & 0.75 & 0.95 & 1.4 & 0.95 & 1.7 \\
\hline slump (mm) & 160 & 130 & 150 & 130 & 120 \\
\hline unit weigth $\left(\mathrm{kg} / \mathrm{m}^{3}\right)$ & 2378 & 2367 & 2356 & 2404 & 2389 \\
\hline air content $(\%)$ & 1.8 & 1.9 & 1.8 & 1.5 & 2.3 \\
\hline
\end{tabular}

Mechanical performance results, related to mortar mixtures at different water-cement ratio, are shown in Fig. (5) (see also Table 5). A mechanical performance decrease can be noted at any UFS dosage; the decrease rate is quite comparable to the replacement amount.

Despite the absolute value of compressive strength, the negative influence ascribed to the presence of UFS in reducing the compressive strength seems greater when lower $\mathrm{w} / \mathrm{c}$ is adopted.

In order to clarify this assertion, the mechanical performance of mortars at same UFS's rate is compared at three different $w / c$ ratio $(0.45,0.50$ and 0.55$)$ in Fig. (6a). Although the absolute value of the compressive strength is high at low w/c ratio, as usual, it achieves negligible advantages when $\mathrm{w} / \mathrm{c}$ is lower than 0.50 . Consequently, the strength reduction due to the presence of UFS cannot be simply recovered by lowering the w/c. Therefore, this solution is not suitable below certain values due to the increasing in superplasticizer addition.
Another widen aspect is the binder effect by comparing the effect on compressive strength of UFS replace when cleaned. In Fig. (6b) the negative influence of binder in reducing the compressive strength seems upheld. Nevertheless, the complexity in pre-treat the UFS doesn't seem justifies the modest increase in mechanical performances; although the modest increase looks incomplete (see in Fig. $6 \mathbf{b}$, curves M2 vs M2-20c).

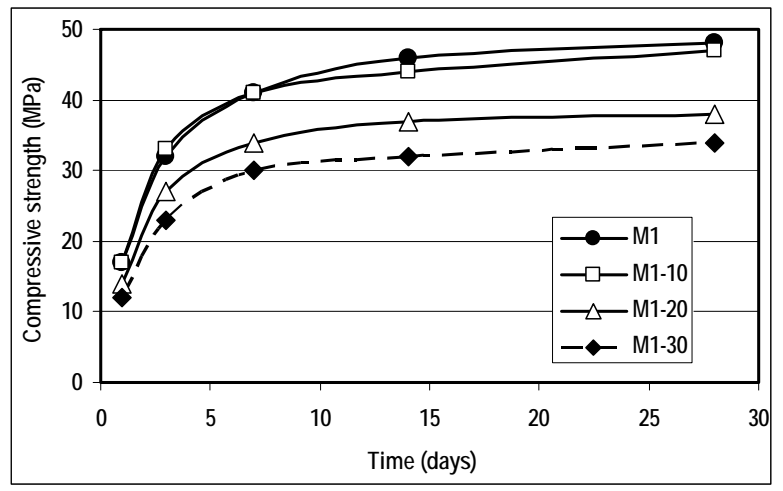

Fig. (5a). Mortar compressive strength results at $\mathrm{w} / \mathrm{c}=0.50$.

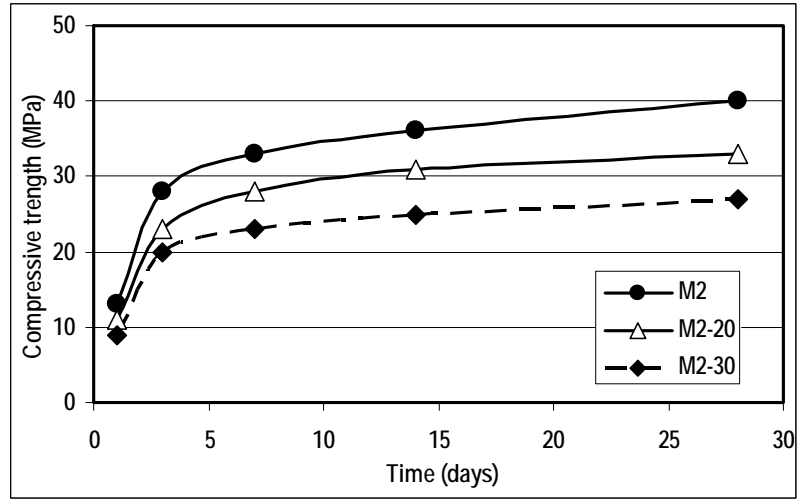

Fig. (5b). Mortar compressive strength results at $\mathrm{w} / \mathrm{c}=0.55$.

As far as concrete mixtures at different water-cement ratio $(0.46,0.50)$ it concerns, they are shown on Fig. (7) (see also Table 6). The considerations on compressive strength deduced from mortars can be extended to concretes mixtures, reinforcing previous results. The compressive strength penalization has to be ascribed to the presence of UFS, as partial replacement of natural sand, and depends on the amount introduced in the mixture.

The compressive strength decrease in cementitious materials is due to the presence of binder in foundry sand, as pointed out in $[20,29,30]$. The binder, composed by a very

Table 5. Mortars Compressive Strength (MPa) as a Function of Time (Days)

\begin{tabular}{|c|c|c|c|c|c|c|c|c|}
\hline MIX & M1 & M1-10 & M1-20 & M1-30 & M2 & M2-20 & M2-30 & M3 \\
\hline \hline 1 day & 17 & 17 & 14 & 12 & 13 & 11 & 9 \\
\hline 3 days & 32 & 33 & 27 & 23 & 28 & 23 & 20 & 27 \\
\hline 7 days & 41 & 41 & 34 & 30 & 33 & 28 & 23 & 32 \\
\hline 14 days & 46 & 44 & 37 & 32 & 36 & 31 & 25 & 35 \\
\hline 28 days & 48 & 47 & 38 & 34 & 40 & 33 & 27 \\
\hline
\end{tabular}


fine powder of carbon and clay, causes a loose of contacts and links between the cement paste and the aggregate. In particular, in case of carbon's binder, a delay in cement hydration it's also possible. As a matter of fact the compressive strength decreases also at very low curing time (i.e. 1 and 3 days in Tables 5 and $\mathbf{6}$ ). Moreover, as previously pointed out in mortars, despite the absolute value of the compressive strength, the negative influence ascribed to the presence of UFS seems greater in presence of low w/c. In effect, compressive strength of concretes with $\mathrm{w} / \mathrm{c}=0.46$ undergoes a heavy penalization of about $30 \%$, instead of about $20 \%$ exhibited by concretes with $\mathrm{w} / \mathrm{c}=0.50$ (Fig. 7). Fig. (7) states that negligible advantages are achieved when w/c goes under 0.50 .

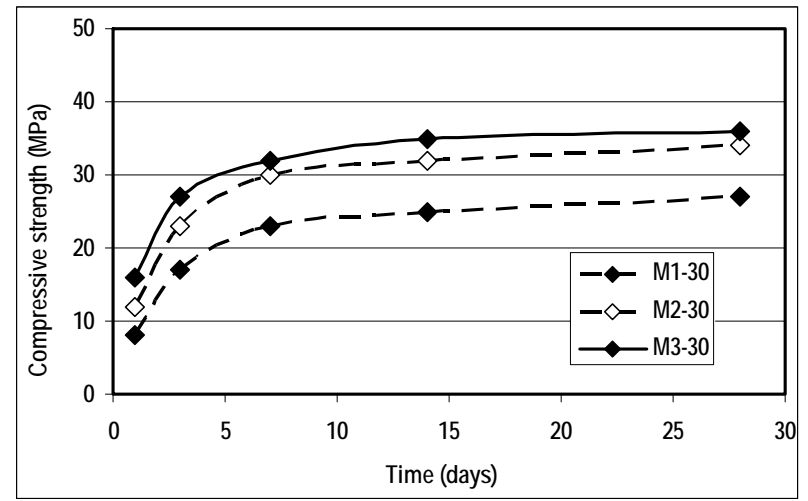

Fig. (6a). Mortar compressive strength at $30 \%$ of UFS dosage and different $\mathrm{w} / \mathrm{c}$ ratio $(\mathrm{M} 1=0.50, \mathrm{M} 2=0.55, \mathrm{M} 3=0.45)$.

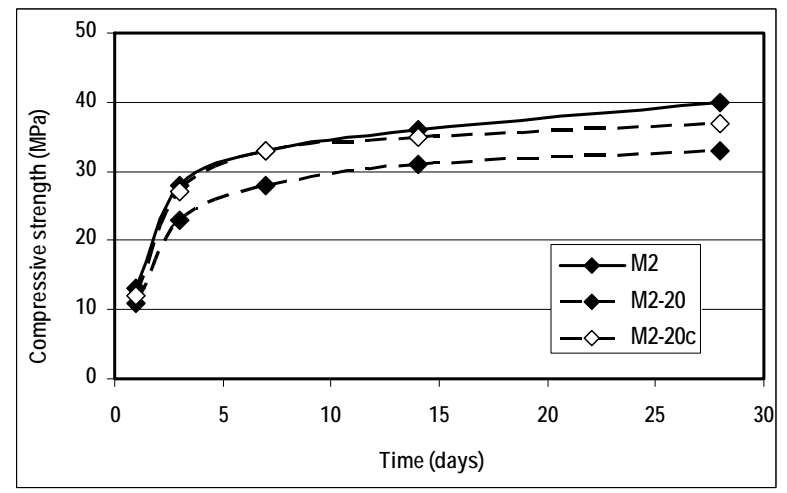

Fig. (6b). Mortar compressive strength at $w / c=0.55$ and different UFS employ (M2, M2-20, M2-20 ).

Table 6. Concrete Compressive Strength (MPa) as a Function of Time (days)

\begin{tabular}{|c|c|c|c|c|c|}
\hline MIX & C1 & C1-7 & C1-10 & C2 & C2-10 \\
\hline \hline 1 day & 18 & 16 & 14 & 26 & 17 \\
\hline 3 days & 31 & 27 & 23 & 34 & 23 \\
\hline 7 days & 36 & 31 & 27 & 43 & 29 \\
\hline 14 days & - & - & - & 52 & 36 \\
\hline 28 days & 45 & 38 & 35 & 56 & 39 \\
\hline
\end{tabular}

In general, the obtained values - ranging from $35 \mathrm{MPa}-$ $40 \mathrm{MPa}$ - although not so performing, could be considered acceptable when compared to those of ordinary conglomerates [31].

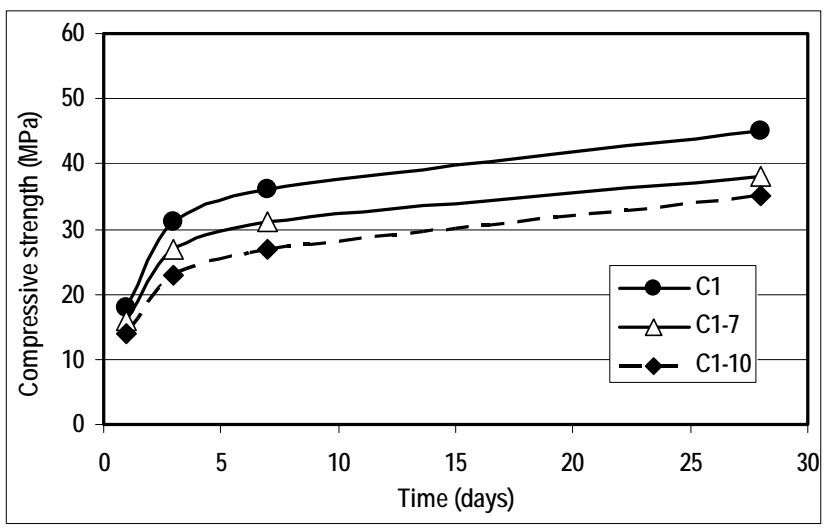

Fig. (7a). Concrete compressive strength results at $\mathrm{w} / \mathrm{c}=0.50$.

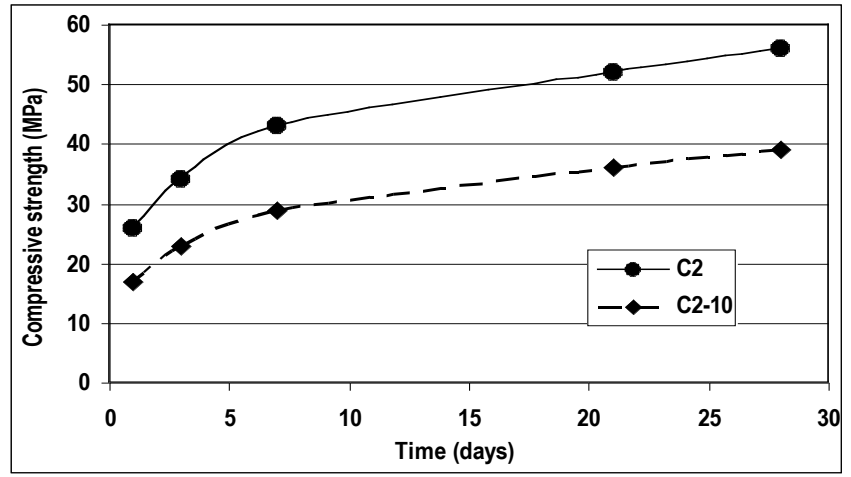

Fig. (7b). Concrete compressive strength results at $w / c=0.46$.

Table 7 shows the dynamic elastic modulus of concretes at 28 days of curing time. Consistent with the compressive strength, the elasticity modulus of concretes with UFS is lower than that of concretes with natural sand. However, differences are very low at that curing time (i.e. 28 days) and don't exceed about $6 \%$. More investigations are needed to justify these poor differences and to establish if they are still confirmed at low curing time (i.e. < 28days). Drying shrinkage results in concretes specimens (Fig. 8) show, as expected that the contraction (due to water loss) is higher when UFS is present in the mixture instead of natural sand. The shrinkage suffers a moderate increase both at short and long curing time.

The increase in drying shrinkage fits well with the results obtained by compressive tests and elasticity modulus determinations. Generally, several factors can affect concrete shrinkage, including paste porosity, aggregate type and volume, modulus of elasticity. As the present study it concerns, an explanation could be find on a possible delay on the cement hydration due to carbon (graphite) particles and/or a loosening of the link between aggregate and cement paste, as above mentioned.

\section{CONCLUSION}

According to the obtained test results, it can be concluded that structural mortar and concrete can be manufactured with UFS as a partial replacement of natural sand. A suitable recycling of the discarded foundry sand as building construction material could be suggested. 


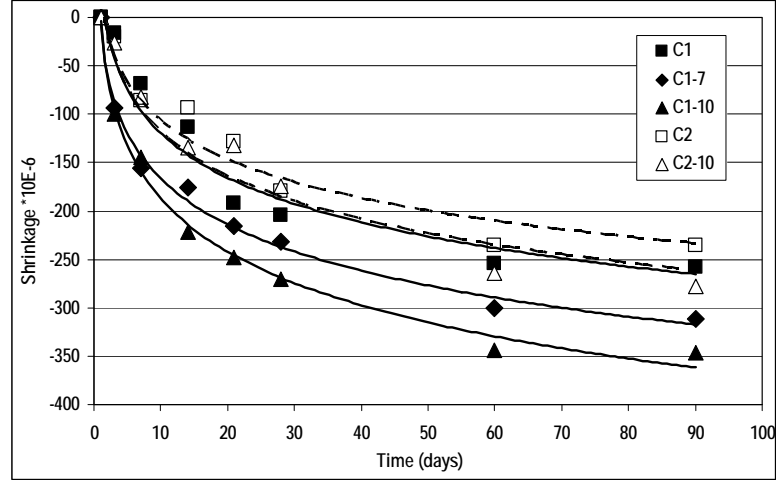

Fig. (8). Concrete drying shrinkage $v s$ time results at $\mathrm{w} / \mathrm{c}=0.50(\mathrm{C} 1)$ and $\mathrm{w} / \mathrm{c}=0.46(\mathrm{C} 2)$.

Table 7. Dynamic Elastic Modulus (MPa) of Different Concrete Mixtures at 28 Days of Curing Time

\begin{tabular}{|c|c|c|c|c|c|}
\hline MIX & C1 & C1-7 & C1-10 & C2 & C2-10 \\
\hline \hline dynamic elastic modulus & 40167 & 40052 & 37632 & 41920 & 39046 \\
\hline
\end{tabular}

The fresh concrete data shows that all mixtures, containing UFS, require high superplasticizer dosage in order to maintain a good workability. Substantially, UFS addition gives low slump (or slump flow) mainly due to the presence of very fine binders. As far as mechanical performances it concerns, mortars containing UFS at watercement ratio equal to 0.5 show a compressive strength lower by about $20-30 \%$ compared to that of the reference mix. Same percentage could be reached in concrete at the same water cement ratio. The modulus of elasticity doesn't vary significantly; in the highest penalization it is about the $94 \%$ of the elastic modulus of the control mix. Drying shrinkage increases with the decrease of mechanical performances.

More investigations are focusing to clarify the influence of UFS on the cement hydration kinetic and on the opportunity to clean UFS from the fine binder.

\section{REFERENCES}

[1] R. Siddique, and A. Noumowec, "Utilization of spent foundry sand in controlled low-strength, materials and concrete", Resour. Conserv. Recycl., vol. 53, pp. 27-35, September 2008.

[2] EPA 329/03: Technical Bulletin No. 23, "Guidelines for the classification and disposal of used foundry sand (UFS)", September 2003.

[3] American Foundry Society (AFS), "About Metal Casting", Reference available from: http://www.afsinc.org/content/view /62/122/ [Accessed September 2009].

[4] Directive 2006/12/EC of the European Parliament and of the Council of 5 April 2006 on waste, Official Journal of the European Parliament, L.114, pp. 9-21, April 2006.

[5] Council Directive of 18 March 1991 amending Directive 75/442/EEC on waste (91/156/EEC), Official Journal L.078, pp. 32-37, March 1991.

[6] R. J. Collins and S. K. Ciesielski, "Recycling and use of waste materials and by-products in highway construction", National Cooperative Highway Research Program Synthesis of Highway Practice 199, Transportation Research Board, Washington DC, 1994.

[7] S. Javed and C. W. Lovell, "Use of foundry sand in highway construction", Joint Highway Research Project No. C-36-50N, Department of Civil Engineering, Purdue University, July 1994.

[8] R. Bakis, H. and Koyuncu, A. Demirbas, "An investigation of waste foundry sand in asphalt concrete mixtures", Waste Manage. Res., vol. 24, pp. 269-274, March 2006
[9] Turner Fairbank Highway Research Center and the Federal Highway Administration, "User guidelines for waste and byproduct materials in pavement construction, Reference available from: http://www.tfhrc. gov/hnr20/recycle/waste/begin.htm. [Accessed October 2009].

[10] "Process for regenerating used foundry sand having high oolitic levels", US Patent 5526937.

[11] M. Korac, M. Gavrilovski, Z. Kamberovic and I. Ilic, "Possibility of used foundry sand exploitation in civil engineering", Acta Metallurgica Slovaca, vol. 12, pp. 203-207, June 2006.

[12] T. R. Naik, V. M. Patel, D.M. Parikh, and M.P. Tharaniyil, "Utilization of used foundry sand in concrete", J. Mater. Civil Eng., vol. 6, pp. 254263, February 1994.

[13] T. R. Naik, S. S. Singh, M. P. Tharaniyil, and R. B. Wendorf, "Application of foundry by-product materials in manufacture of concrete and masonry products", ACI Mater. J., vol.93, pp. 41-50, January 1996.

[14] American Foundry Society (AFS), "Foundry industry benchmarking survey: Industry practices regarding the disposal and beneficial reuse of foundry sand - results and analysis", August 2007. Reference available from: http://www.strategicgoals.org/ benchmarking/foundry.html [Accessed: September 2009].

[15] American Foundry Society, "Materials characterization paper. In support of the advanced notice of proposed rulemaking - Identification of nonhazardous materials that are solid waste foundry sand used as ingredient in clinker manufacture", December 2008. Reference available from: http://www.afsinc.org/content/ view/62/122/. [Accessed October 2009].

[16] Foundry Industry Recycling Stars Today, "Foundry Sand in Portland Cement Manufacturing", Reference available from: http://www.foundryrecycling.org/TechnicalApplications/Manufactured Products/PortlandCement/tabid/173/Defaultaspx. [Accessed June 2009].

[17] Foundry Industry Recycling Stars Today, "What is Recycled Foundry Sand?", Reference available from: http://www.foundryrec ycling.org/Home/WhatisRecycledFoundrySand/tabid/294/Default.aspx. [Accessed June 2009].

[18] F. Tittarelli, S. Monosi, M. L. Ruello and G. Moriconi, "Recent investigation on used foundry sand in mortars mixtures", In: P. R. Gupta, T. C. Holland, V. M. Malhotra., Recent Advances in Concrete Technology and Sustainability Issues, Farminton Hills: American Concrete Institute, pp. 245-252, 2009.

[19] S. Monosi, F. Tittarelli, M. L. Ruello and G. Moriconi, "Effect of used foundry sands addition on mechanical performance of cement mortars", submitted at the "Second International Conference on Sustainable Construction Materials and Technologies", Ancona, Italy, June 28-30, 2010.

[20] U. Mroueh .and M. Wahlstrom, "By-products and recycled materials in earth construction in Finland - an assessment of applicability", Resour. Conserv. Recycl., vol. 35, pp.117-129, 2002.

[21] T. R. Naik, S. S. Singh. and B. Ramme, "Performance and leaching assessment of flowable slurry", J. Environ. Eng., vol. 127, pp. 359-368, April 2001.

[22] American Foundry Society, "Alternative utilization of foundry waste sand. Final Report (Phase I)", prepared by American Foundrymen's Society Inc. for Illinois Department of Commerce and Community Affairs, Des Plaines, IL; 1991.

[23] T. R. Naik, "Foundry industry by-product utilisation", Report $\mathrm{N}^{\circ} \mathrm{CBU}-$ 1989-81, Ed. Center for By-Products Utilization, University of Wisconsin-Milwaukee, Milwaukee, Wisconsin, February 1989.

[24] T.R. Naik. and V.M. Patel, "Utilization of used foundry sand: current state of the knowledge", Report No. CBU-1992-02, Ed. Center for ByProducts Utilization, University of Wisconsin-Milwaukee, Milwaukee, Wisconsin, February 1992.

[25] T.R. Naik, V.M. Patel, D.M. Parikh, and M.P. Tharaniyil, "Utilization of used foundry sand: characterization and products testing", Report No. CBU-1992-20, Center for By-Products Utilization, University of Wisconsin-Milwaukee, Milwaukee, Wisconsin, June 1992.

[26] Decreto Legislativo 3 aprile 2006, n. 152 "Norme in materia ambientale", Gazzetta Ufficiale n. 88 - Supplemento Ordinario n. 96, Aprile 2006.

[27] Decreto 27 luglio 2004 del Ministero dell'Ambiente e della Tutela del Territorio. "Integrazione della voce 13.18, Allegato 1, Suballegato 1 , del decreto 5 febbraio 1998, recante individuazione dei rifiuti non pericolosi sottoposti alle procedure semplificate di recupero, ai sensi degli articoli 31 e 33 del decreto legislativo 5 febbraio 1997" n. 22", Gazzetta Ufficiale n. 180, Agosto 2004. 
[28] Decreto del 30 Agosto 2005 del Ministero dell'Ambiente e della Tutela del Territorio. "Definizione dei criteri di ammissibilità dei rifiuti in discarica", Gazzetta Ufficiale n. 201, Agosto 2005.

[29] T.R. Naik, R. N. Kraus, Y. M. Chun, B. M. Ramme, and S. S. Shiw, "Properties of field manufactured cast-concrete products utilizing recycled materials", Mater. Civil Eng., vol. 15, pp. 400-407, April 2003.
[30] R. Siddiquea, G. de Schutterb, and A. Noumowec, "Effect of usedfoundry sand on the mechanical properties of concrete", Constr. Build. Mater., vol. 23, pp. 976-980, February 2009.

[31] M. Collepardi, The New Concrete,, Grafiche Tintoretto, Italy, 2006.

Received: March 27, 2010

Revised: April 22, 2010

Accepted: May 3, 2010

(C) Monosi et al.; Licensee Bentham Open.

This is an open access article licensed under the terms of the Creative Commons Attribution Non-Commercial License (http://creativecommons.org/licenses/by$\mathrm{nc} / 3.0 /$ ) which permits unrestricted, non-commercial use, distribution and reproduction in any medium, provided the work is properly cited. 